\title{
Assessing the Relationship between Air Mass Age and Summer Ozone Episodes Based on Photochemical Indices
}

\author{
Kuo-Hsin Tseng ${ }^{1}$, Jia-Lin Wang ${ }^{2}$, Man-Ting Cheng ${ }^{1}$, Ben-Jei Tsuang ${ }^{\text {* }}$ \\ ${ }^{1}$ Department of Environmental Engineering, National Chung-Hsing University, \\ Taichung, 402, Taiwan \\ ${ }^{2}$ Department of Chemistry, National Central University, Taoyuan, 320, Taiwan
}

\begin{abstract}
Although pollutant sources are usually in urban and industrialized areas, poor air quality is frequently encountered in downwind rural areas. This study utilized a tethered balloon to measure the pollutant concentrations in a downwind side (Caotun) of the Taichung Basin during the summer of 2002. Furthermore, an annular denuder system (ADS) was used to measure $\mathbf{P M}_{2.5}$ and gaseous pollutant concentrations. Concentrations of 55 VOCs species were measured continuously by a network of photochemical assessment monitoring stations in central Taiwan. This study discusses the correlation between the ozone concentration and the routes of an air mass during ozone episodes. Backward trajectory, ratio of particulate matter and photochemical indices were used to examine the aging degree of an air mass. During ozone episodes, the trajectory distribution had a clear sea-land breeze mechanism with a relatively slow wind speed, and the air mass primarily entered through the western coastal industrial area. Analytical results demonstrate that daytime ozone concentrations accompany $\mathrm{HNO}_{3}$ concentrations by photochemical reactions and depend on the previous night's $\mathrm{HNO}_{2}$ concentration. The sulfur and nitrogen conversion ratios, and the photochemical indices (ethylbenzene/m,p-xylene, n-pentane/t-2-pentene and $\mathrm{NO}_{2} / \mathrm{NO}$ ) increased with the ozone concentration. The downwind photochemical indices were strongly correlated with ozone concentration and were higher than those upwind. These phenomena indicate that the air mass during ozone episodes belongs to the "more aged" category.
\end{abstract}

Keywords: Ozone; Aerosol; Aging; Backward trajectory; Conversion ratio; Photochemical index.

\section{INTRODUCTION}

* Corresponding author: Tel.: +886-4-22853411;

Fax: +886-4-22862587

E-mail address: tsuang@nchu.edu.tw
Air pollution is a typical consequence of industrialization and urbanization. Vehicular emissions, crustal materials, secondary 
aerosols, biomass burning and industrial emissions are the major pollution sources in Taiwan's urban areas (Chio et al., 2004; Kuo et al., 2007). In particular, ozone episodes typically occur during warm, sunny, and relatively stagnant conditions (Vukovich et al., 1977; Logan, 1989). According to data for the last 10 years, central Taiwan has had poor air quality (Taiwan EPA, 2003). Especially, the number of summer episodes has been increased significantly in recent years (Fig. 1). This study presents the first field campaign data in central Taiwan during the summer, when a few ozone episodes were observed.

Photochemical smog is a major secondary pollution phenomenon in urban and downwind areas. The key pollutants of this smog are gaseous pollutants such as: ozone $\left(\mathrm{O}_{3}\right)$, nitrogen dioxide $\left(\mathrm{NO}_{2}\right)$, nitrous acid $\left(\mathrm{HNO}_{2}\right)$, nitric acid $\left(\mathrm{HNO}_{3}\right)$, peroxy acetyl nitrate (PAN) and polycyclic aromatic hydrocarbons (PAHs) (Wang et al., 2007a; b). Once emitted into the atmosphere, primary pollutants are transported downwind with air masses, providing more reaction time to generate secondary pollutants. The reaction mechanism includes gas phase reactions and heterogeneous reactions: for example, $\mathrm{NO}_{\mathrm{x}}$ produces $\mathrm{O}_{3}$ through photochemical reactions, and $\mathrm{SO}_{2}$ and $\mathrm{NO}_{\mathrm{x}}$ produce sub-micron aerosols via photochemical reactions (Seinfeld, 1986; Pilinis et al., 1987; Rastogi and Sarin, 2006; Lin et al., 2008). The generation and accumulation of secondary pollutants indicate that an air mass has aged.

Ozone is a secondary pollutant formed by its precursors (nitrogen oxide $\left(\mathrm{NO}_{\mathrm{x}}\right)$ and volatile organic compounds (VOCs)) through chemical reactions or physical mechanisms. The main sources of $\mathrm{NO}_{\mathrm{x}}$ are vehicular emissions and industrial areas (Wang et al., 2004). Additionally, VOCs and their products, free radicals (i.e. $\mathrm{OH}$ radical) (Seinfeld and Pandis, 1998), are other important ozone

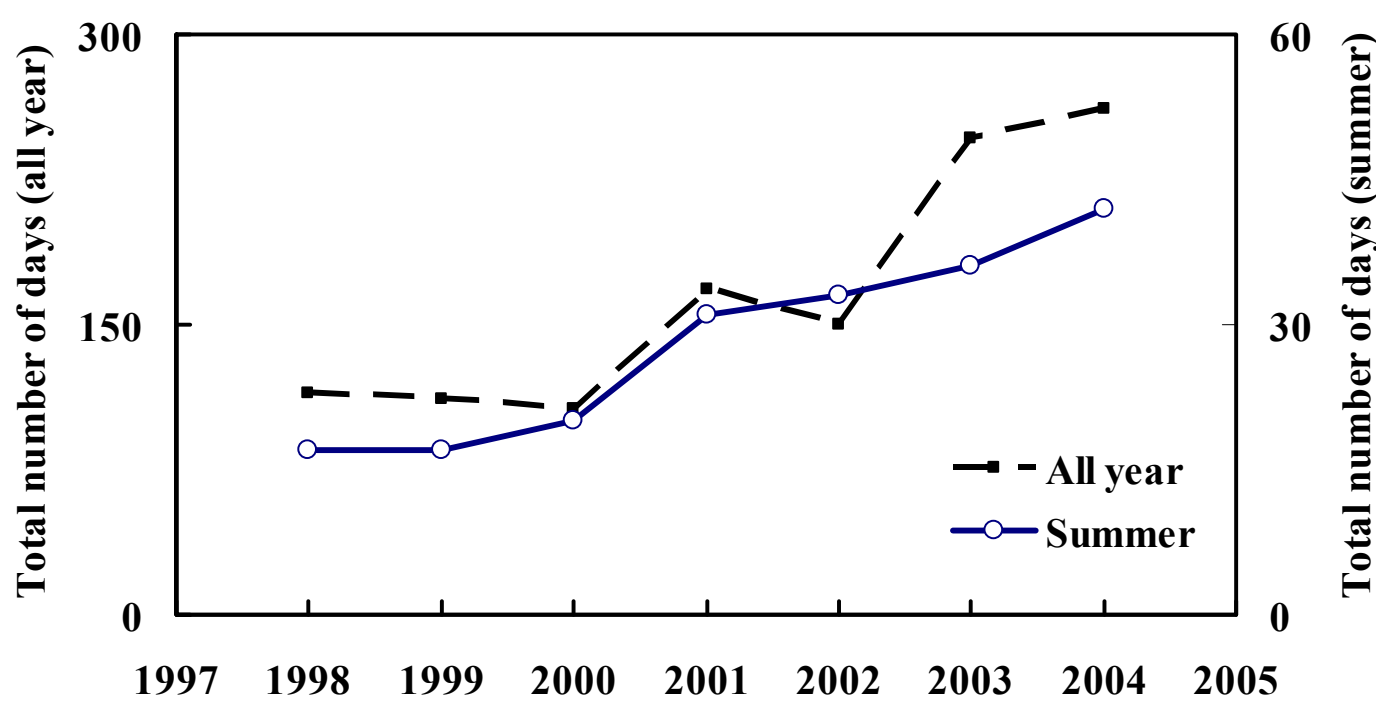

Fig. 1. Sum of the numbers of ozone episode days at 4-inland EPA stations (Dali, Nantou, Jhushan and Puli) in central Taiwan in the entire year and in summer (June-August) from 1998 to 2004. 
precursor. Notably, VOCs have numerous sources, which include emission from vehicles, industrial areas and plants. After the phenomenon in which reduction chemical materials react with $\mathrm{OH}$ radicals, a series of reactive free radicals can be produced and produce ozone under the photochemistry of $\mathrm{NO}_{\mathrm{x}}$ and sunlight (Carter, 1994).

The photochemical assessment monitoring stations (PAMS) collect detailed data for VOCs concentrations. These data help Taiwan Environmental Protection Administration (EPA) to understand the underlying causes of ozone pollution, thereby aiding in the development of effective remedies and assessment of environmental improvement.

Atmospheric particulate matter (PM) can be produced from various gases during the particle conversion process. Consequently, the composition of $\mathrm{PM}$ is complex and generally includes sulfates $\left(\mathrm{SO}_{4}^{2-}\right)$, nitrates $\left(\mathrm{NO}_{3}^{-}\right)$, and carbonaceous materials (Matsumoto and Okita, 1998). Particulate $\mathrm{SO}_{4}^{2-}$ and $\mathrm{NO}_{3}^{-}$are converted by sulfur dioxide $\left(\mathrm{SO}_{2}\right)$ and $\mathrm{NO}_{2}$, respectively. The exact conversion mechanisms and rates of formation of $\mathrm{SO}_{4}^{2-}$ and $\mathrm{NO}_{3}^{-}$are, however, unknown. The sulfur conversion ratio increases as the $\mathrm{O}_{3}$ concentration and relative humidity increase (Kobara et al., 2007). The nitrogen conversion ratio also increases as the ozone concentration increases; here gas-phase reactions play an important role in the oxidation of $\mathrm{NO}_{2}$ to $\mathrm{NO}_{3}^{-}$ (Khoder, 2002). Notably, the $\mathrm{O}_{3}$ concentration is moderately correlated with total $\mathrm{SO}_{4}^{2-}$ and $\mathrm{NO}_{3}^{-}$concentrations during $\mathrm{O}_{3}$ episode days. When the relative humidity is $<70 \%, \mathrm{SO}_{4}^{2-}$,
$\mathrm{NO}_{3}^{-}$, carbonaceous, and $\mathrm{PM}_{10}$ masses are strongly correlated with the maximum hourly average ozone concentration (Tsai and Perng, 1998).

The composition and reaction of these pollutants are very complex; under the same pollution emission levels, can result from the influences of different meteorological factors (Reddy et al., 2007; Wang et al., 2008a, 2008b; Dubey et al., 2008). Trajectory analysis can be of assistance in understanding the transmission of air masses and pollution sources during a deteriorated air-quality day (Begum et al., 2007; Wang et al., 2008a). A trajectory plume model was utilized in this study to calculate the backward trajectories of air masses and the contributed contributions of emission sources along the routes of trajectories.

This study utilized a tethered balloon to acquire the vertical profiles of airborne pollutant concentrations and meteorological variables; measurements were made up to a height of $1200 \mathrm{~m}$ at a rural site in Caotun, center Taiwan, during the summer of 2002 (120³9'29.1" E, 2359'12.1" N, $110 \mathrm{~m}$ above sea level (ASL), Fig. 2). Additionally, surface $\mathrm{PM}_{2.5}$ and VOCs concentrations were measured simultaneously in central Taiwan during the field campaign. All data were utilized to discuss the correlation between $\mathrm{O}_{3}$ concentration and the transmission of air masses during the study period. The ratios of PM and photochemical indices were employed to discuss whether the air mass was fresh or aged. 


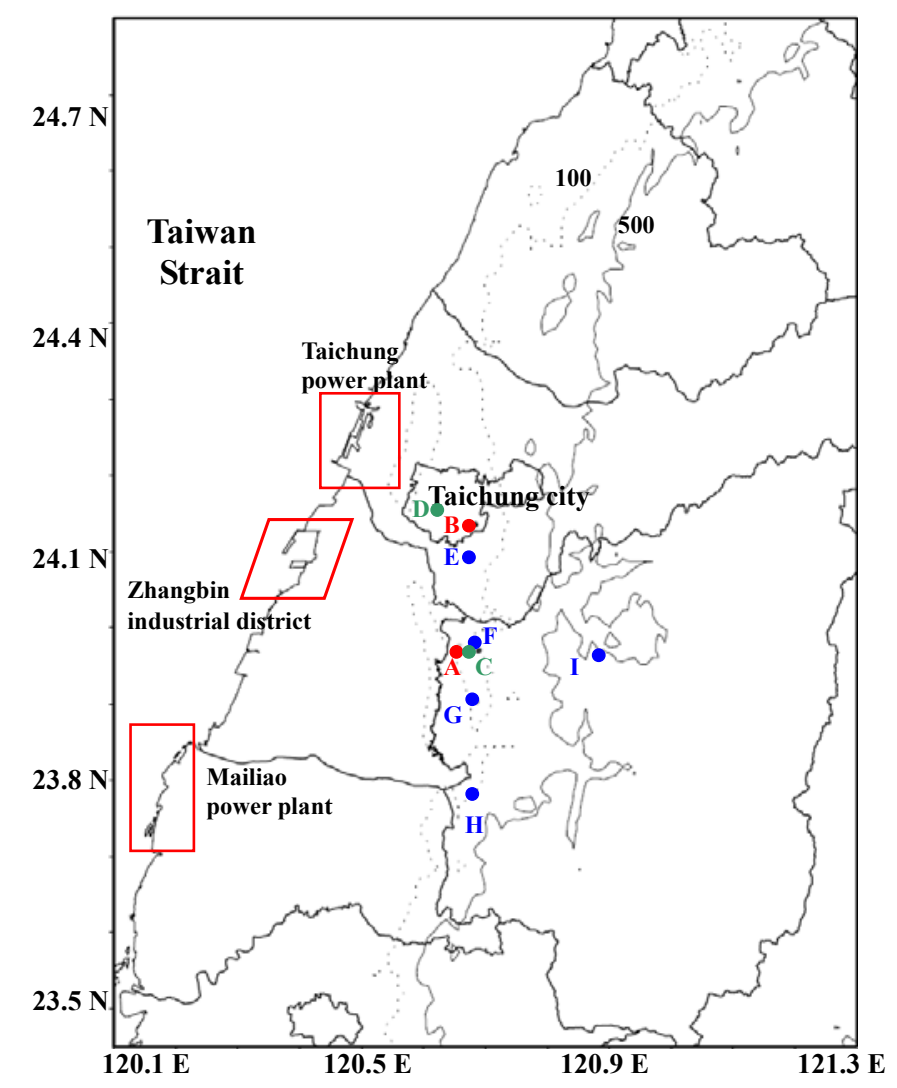

Fig. 2. Map of Central Taiwan shows the study site at Caotun (tethersonde site, A), NCHU (PM site, B), Caotun (PAMS site, C), Chonlun (PAMS site, D), Dali (E), Caotun (F), Nantou (G), Jhushan (H) and Puli (I). The height contours of $100 \mathrm{~m}$ (short dash) and $500 \mathrm{~m}$ (solid thin) are also shown.

\section{METHODOLOGY}

\section{Field Campaign Description}

The field campaign utilized a tethersonde system to measure the vertical profiles of air pollutants, wind vector, air temperature and humidity at a downwind rural site (Caotun) in central Taiwan, during Aug. $15^{\text {th }}-26^{\text {th }}, 2002$. Additionally, the ADS was utilized to collect $\mathrm{PM}_{2.5}$ and gaseous samples to measure the $\mathrm{PM}_{2.5}$ and gaseous pollutant concentrations from Aug. $16^{\text {th }}-26^{\text {th }}, 2002$, at $\mathrm{NCHU}$ in Taichung City. Surface speciated VOCs measurements were performed by a network of two PAMS (Chonlun and Caotun) in central
Taiwan. All data obtained in August 2002 from Chonlun and Caotun stations are discussed.

The major pollution sources near the study site (Caotun) are local traffic, Taichung City and industrial areas located along the coast. Taichung is a commercial metropolitan city with a population exceeding 1 million. Moreover, the Taichung Power Plant (TP), Mailiao Power Plant (MP) and Zhangbin industrial district are located along the coast.

During the field campaign, except under the conditions of rain, strong wind (wind speed $>$ $10 \mathrm{~m} / \mathrm{s}$ ) or instrument malfunction (i.e. power failure), the air pollutant sampling system was 
implemented at 3-h intervals 00, 03, 06, 09, 12, 15, 18 and 21 LT ("LT" is the acronym of "Local time"). The sampling system consists of a timer, a pump and two Teflon sampling bags (SKC, Cat \#232-08). A specially designed lightweight (600 g) sampling pump with a timer was utilized to inflate two Teflon sampling bags. This study focuses on concentrations of air pollutants at the surface (10 $\mathrm{m}$ above ground level, agl). After sampling for $10 \mathrm{~min}$, the sampling bags were analyzed for $\mathrm{NO}, \mathrm{NO}_{2}, \mathrm{NO}_{\mathrm{x}}$ and $\mathrm{O}_{3}$ concentrations. Table 1 lists instrument details. Further details regarding the tethersonde system can be found in Chen et al. (2002). The monitoring equipment for analyzing air pollutants is similar to that used by Taiwan's air-quality monitoring stations. All analyzers were calibrated using standard gases prior to the field campaign. The $\mathrm{O}_{3}$ generated by an ozone generator and standard $\mathrm{CO}, \mathrm{SO}_{2}, \mathrm{NO}$ and $\mathrm{NO}_{\mathrm{x}}$ calibration gases were used for data quality assurance. A time lag of 5-35 min occurred between sampling and analysis; thus, the data were further calibrated to offset adsorption by sampling bags. Decay factors for $\mathrm{NO}, \mathrm{NO}_{\mathrm{x}}$ and $\mathrm{O}_{3}$ when stored for $5 \mathrm{~min}$ are $0.94,0.93$ and 0.68 , respectively. For further details regarding calibration procedures, see Chen et al. (2002). The correlation between concentrations measured at the study site (Caotun) and the Dali air-quality monitoring stations $\left(120^{\circ} 40^{\prime} 40.0^{\prime \prime}\right.$ E, 2405'58.1" $\left.\mathrm{N}\right)$ operated by Taiwan EPA (Fig. 2), were acceptable. Those correlation coefficients (r) are $0.98,0.50$ and 0.89 for of $\mathrm{O}_{3}, \mathrm{NO}$ and $\mathrm{NO}_{\mathrm{x}}$, respectively (Table 1 ).

The ADS was employed for sampling gaseous $\left(\mathrm{HNO}_{2}, \mathrm{HNO}_{3}, \mathrm{SO}_{2}\right.$ and ammonia $\left(\mathrm{NH}_{3}\right)$ ) and fine aerosol species (ammonium $\left(\mathrm{NH}_{4}^{+}\right), \mathrm{NO}_{3}^{-}$and $\left.\mathrm{SO}_{4}^{2-}\right)$. The ADS inlet contained a Teflon-coated aluminum cyclone

Table 1. Instrument specifications, the average, maximum and minimum concentrations for each air pollutant.

\begin{tabular}{lcc}
\hline & Ozone & NO / NOx \\
\hline Type & TECO model 49* & TECO model 42 \\
Theorem & U.V. photometric & Chemiluminescence \\
Sample range (ppb) & $0-1000$ & $0-20000$ \\
Response time (sec) & 20 & 30.0 \\
Detection limit (ppb) & 2.0 & 0.5 \\
Precision (ppb) & 2.0 & 0.5 \\
Flow (L/min) & $1-3$ & 0.65 \\
\hline Calibration (adsorption) ${ }^{(}$ & 0.68 & $0.94 / 0.93$ \\
Correlation (Dali) & 0.98 & $0.50 / 0.89$ \\
\hline Average (ppb) & 39.1 & $2.0 / 20.8$ \\
Maximum (ppb) & 104.2 & $8.8 / 63.4$ \\
Minimum (ppb) & 8.9 & $0.7 / 10.4$ \\
\hline
\end{tabular}

*: TECO is Thermo Environmental Corporation, Franklin, Massachusetts.

@: Further calibrated to offset adsorption by sampling bags (Chen et al., 2002) 
with a $10 \mathrm{~L} / \mathrm{min}$ flow rate to remove coarse particles (aerodynamic diameters large than $2.5 \mu \mathrm{m})$. The first denuder in the cyclone was coated with $\mathrm{Na}_{2} \mathrm{CO}_{3} \quad(1 \%$ glycerol in methanol/water) to collect $\mathrm{HNO}_{2}, \mathrm{HNO}_{3}$ and $\mathrm{SO}_{2}$. The second denuder was coated with citric acid to collect $\mathrm{NH}_{3}$.

The particulate $\left(\mathrm{PM}_{2.5}, \mathrm{SO}_{4}^{2-}, \mathrm{NO}_{3}^{-}, \mathrm{NH}_{4}^{+}\right.$ and $\mathrm{Na}^{+}$) samples were collected on the Teflon filter. A nylon filter was utilized to collect particulate $\mathrm{NO}_{3}^{-}$that may have evaporated from the Teflon. After each sampling, the first and second denuder samples were extracted with $10 \mathrm{ml}$ ultra-pure water. All extracts were transferred to a $20-\mathrm{ml}$ glass tube and stored at $4^{\circ} \mathrm{C}$ until analysis. The Teflon and nylon filters were cut into pieces and placed in a vial containing $10 \mathrm{ml}$ ultrapure water, and sonicated for $90 \mathrm{~min}$. The extracted solution was filtered through a mixed cellulose-esters filter with a pore size of $0.22 \mu \mathrm{m}$ and stored in a refrigerator at $4^{\circ} \mathrm{C}$ until analysis. All extracts and $\mathrm{SO}_{4}^{2-}, \mathrm{NO}_{3}^{-}$, $\mathrm{NH}_{4}^{+}$and $\mathrm{Na}^{+}$concentrations were determined by Dionex ion chromatography (Dionex DX 100). The method for sampling PM concentrations is in accordance with the standard method of the U.S. Environmental Protection Agency (US EPA, 1999). The ADS was employed to collect air samples; sampling flow rate was $10 \mathrm{lpm}$. Prior to sampling, a dry flow meter (DC-2, Shinagawa Aeiki) was used for calibration.

Surface speciated VOCs measurements were performed by the network of PAMS at Chonlun and Caotun. The PAMS at Chonlun was characterized as an upwind system and that at Caotun as downwind. This network performs year-round hourly measurements of 55 VOCs from $\mathrm{C}_{2}-\mathrm{C}_{12}$. Refer to Wang et al. (2005) and Yang et al. (2005) for additional details of the PAMS. Chonlun and Caotun PAMSs were established followed the protocol of U.S. PAMS. Each PAMS includes an automatic VOCs analytical system (U.S. Perkin Elmer). The analytical equipment automatically calibrates to zero daily. The EPA performs span calibration monthly to maintain the accuracy and sensitivity of instruments. The Caotun PAMS (120 41'18.5" $\left.\mathrm{E}, 23^{\circ} 58^{\prime} 44.9^{\prime \prime} \mathrm{N}\right)$ is closest to the campaign site (within $4 \mathrm{~km}$ radius); the hourly VOC data facilitate balloon data interpretation. All August 2002 data were discussed along with ozone data collected by the field campaign and in the vicinity for better assess their correlation at the surface.

This study focuses on the correlation between $\mathrm{O}_{3}$ concentration and air mass transmission during the ozone episodes. First, the experimental location was set as the receptor, and the trajectory model was used to calculate the distribution of backward trajectories and the contribution of each pollution source. Second, based on the relationship between primary and secondary pollutants as well as the differences of the reaction rate constant, this study discuss the concentration or ratio variable of particular pollutant, including the formation mechanism of $\mathrm{HNO}_{3} / \mathrm{HNO}_{2}$ and the ratio change of VOCs pollutants. According to the process and numerical variations of these reactions, this study discusses the effects of air mass aging 
and its correlation with $\mathrm{O}_{3}$ production.

\section{Model System}

The GTx consists of a main program (gtx.980) and its matching wind field trajectory model (Traj.64) (Tsuang, 2003; Tsuang et al., 2003). This model can be used to identify pollutant sources and the contribution of pollutants of a receptor. This trajectory modeling system has been certified by the Taiwan EPA. This GTx mode was combined with the Gaussian diffusion mechanism and used variable wind direction, stability, and mixing height in calculating the backward trajectories. The situation of fixed plume direction in the traditional Gaussian mechanism is improved. In addition to the dry deposition mechanism and wash effect (Padro et al., 1991), GTx is also considered as a mechanism for producing secondary aerosols from $\mathrm{SO}_{2}$ and $\mathrm{NO}_{\mathrm{x}}$.

Hourly surface wind data were obtained from stations maintained by Central Weather Bureau (CWB/Taiwan), EPA/Taiwan and Taiwan Power Company. The distance between surface observation sites over land is about $10 \mathrm{~km}$. In addition the vertical profiles of wind and air temperature collected by the tethersonde system were used for determining the mixing height and the trajectories. To compensate for the unequal distribution of the observation stations, the weight of the distance, angle and height of receptors relative to the observation station were added to this model. Since the temporal and the spatial resolutions of the wind data were dense, the derived trajectories are less problematic and it is possible to capture the diurnal variation of wind direction in the study site. The aerodynamic roughness of the study site grid is set at $0.4 \mathrm{~m}$ according to Tsai and Tsuang (2005). 3-D back trajectories for $72 \mathrm{~h}$ of transport arriving at the receptor site at $50 \mathrm{~m}$ above ground level (agl) were computed from wind field data interpolated from surface meteorological stations and adjusted to the trajectory height according to a power-law profile.

\section{Reaction Mechanism}

The formation mechanisms of $\mathrm{SO}_{4}^{2-}$ in particles include a heterogeneous reaction and a homogeneous reaction. Feichter (1996) determined that $66 \%$ of $\mathrm{SO}_{4}^{2-}$ in particles in the atmosphere are generated by the heterogeneous reaction mechanism, which is shown in the following equation. The $\mathrm{SO}_{2}$ reacting with $\mathrm{H}_{2} \mathrm{O}_{2}$ accounts for $59 \%$ of $\mathrm{SO}_{4}^{2-}$ in particles in the atmosphere (Eqs. (1) and (2)), and reacts with $\mathrm{O}_{3}$ to account for the remaining 7\% (Eqs. (1) and (3)) (Matsumoto and Tanaka, 1996; Seinfeld and Pandis, 1998). Most $\mathrm{SO}_{2}$ is emitted by point sources and $\mathrm{S}(\mathrm{VI})$ is the $\mathrm{SO}_{4}^{2-}$ generated by the reaction.

$$
\begin{aligned}
& \mathrm{SO}_{2(\mathrm{~g})}+\mathrm{H}_{2} \mathrm{O}_{(\mathrm{aq})} \rightarrow \mathrm{H}_{2} \mathrm{SO}_{3(\mathrm{aq})} \rightarrow \mathrm{H}_{(\mathrm{aq})}^{+}+\mathrm{HSO}_{3(\mathrm{aq})}^{-} \\
& \rightarrow \mathrm{H}_{(\mathrm{aq})}^{+}+\mathrm{SO}_{3(\mathrm{aq})}^{2-} \\
& \mathrm{H}_{2} \mathrm{O}_{2(\mathrm{~g})} \rightarrow \mathrm{H}_{2} \mathrm{O}_{2(\mathrm{aq})} \stackrel{\mathrm{S}(\mathrm{IV})_{(\mathrm{aq})}}{\longrightarrow} \mathrm{S}(\mathrm{VI})_{(\mathrm{aq})}+\mathrm{H}_{2} \mathrm{O}_{(\mathrm{aq})}
\end{aligned}
$$

$\mathrm{O}_{3(\mathrm{~g})} \rightarrow \mathrm{O}_{3(\mathrm{aq})} \stackrel{\mathrm{s}(\mathrm{IV})_{(\mathrm{aq})}}{\longrightarrow} \mathrm{S}(\mathrm{VI})_{(\mathrm{aq})}+\mathrm{O}_{2(\mathrm{aq})}$ 
The formation mechanisms of the $\mathrm{NO}_{3}^{-}$in particles also include both heterogeneous reaction and homogeneous reaction. Traffic and point sources (such as a power plant) emit most $\mathrm{NO}_{\mathrm{x}}$. These pollutants enter into a series of complex chemical reactions with $\mathrm{OH}$ in the atmosphere to form $\mathrm{HNO}_{3}$. Eq. (4) is the homogeneous reaction mechanism of $\mathrm{HNO}_{3}$ generated by the reaction of $\mathrm{NO}_{2}$ and $\mathrm{OH}$ radicals. The $\mathrm{OH}$ concentration in the daytime is higher than that at nighttime; thus, this reaction is more significant in the daytime. The hydrolysis reaction of $\mathrm{N}_{2} \mathrm{O}_{5}$ mainly occurs in the heterogeneous reaction (Eq. (5)). During the daytime, $\mathrm{NO}_{3}^{-}$free radicals easily undergo photolysis under sunlight; thus, the $\mathrm{NO}_{3}^{-}$ concentration is very low, and the concentration of its product, $\mathrm{N}_{2} \mathrm{O}_{5}$, is also too low. The hydrolysis reaction of $\mathrm{N}_{2} \mathrm{O}_{5}$ in the daytime is not the predominant mechanism forming $\mathrm{HNO}_{3}$. Conversely, $\mathrm{NO}_{3}^{-}$is not the result of photolysis at night; thus, the hydrolysis reaction of $\mathrm{N}_{2} \mathrm{O}_{5}$ is the heterogeneous mechanism forming $\mathrm{HNO}_{3}$ (Geyer et al., 2001; Matsumoto et al., 2005; Jekin, 2000).

$$
\mathrm{NO}_{2(g)}+\mathrm{OH}_{(g)} \underset{h v}{\stackrel{M}{\rightleftarrows}} \mathrm{HNO}_{3(g)}
$$

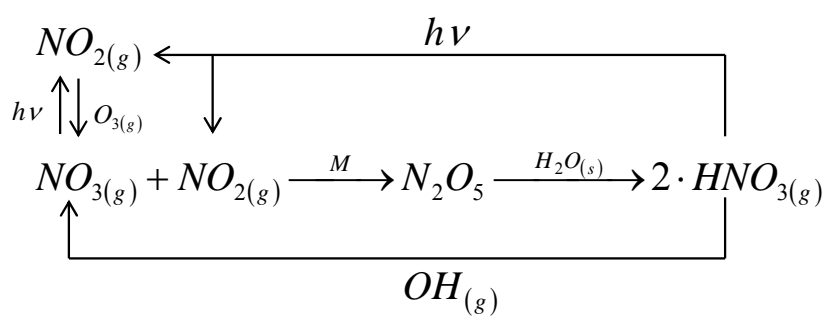

As stated, the mechanisms forming $\mathrm{SO}_{4}^{2-}$ and $\mathrm{NO}_{3}^{-}$, are present when $\mathrm{SO}_{4}^{2-}, \mathrm{NO}_{3}^{-}$or $\mathrm{HNO}_{3}$ are detected, which indicates that pollutants in the air mass have remained in the atmosphere for a long time. The primary pollutants have already gone through a series of chemical reactions and formed secondary pollutants. The higher the proportion of secondary pollutants is contained in the air mass, presumably, the longer the reaction time of pollutants in the air mass, this can also represent the aging degree of the air mass.

\section{Photochemical Index}

It was noted that $\mathrm{O}_{3}$ is a secondary pollutant generated by photochemical reactions, its level is controlled by the primary pollutants, as well as the dynamics and time of the photochemical reaction. In the context of dynamics, the concentration of the primary pollutants decrease gradually as reaction time increases, and the pollutants with higher reactivity towards $\mathrm{OH}$ radical decrease more rapidly than those with lower reactivity. For instance, ethylbenzene, m-xylene and p-xylene all came from vehicle exhaust; their reaction rates were $7.1 \times 10^{-12} \mathrm{~cm}^{3} /$ molecule $/ \mathrm{s}, 23.6 \times 10^{-12}$ $\mathrm{cm}^{3} / \mathrm{molecule} / \mathrm{s}$ and $14.3 \times 10^{-12}$ $\mathrm{cm}^{3} /$ molecule/s, respectively. Since m-xylene and p-xylene cannot be separated by chromatography, they were reported as a combined value (m, p-xylene). Furthermore, similar to ethylbenzene and m,p-xylene, another pair of VOCs, i.e., n-pentane and t-2pentene, were also selected; the reaction rates were different by 20 times (n-pentane $=3.94 \times$ 
$10^{-12} \mathrm{~cm}^{3} /$ molecule $/ \mathrm{s}, \mathrm{t}-2$-pentene $=67 \times 10^{-12}$ $\left.\mathrm{cm}^{3} / \mathrm{molecule} / \mathrm{s}\right)$. As a result, it is a more sensitive age indicator than ethylbenzene/m,pxylene.

As an air parcel is transported downwind from a source area, these ratios tend to increase when subjected to photochemical processes, but the increase in n-pentane/t-2pentene should be more pronounced than that in ethylbenzene/m,p-xylene. Using these two pairs for age indication facilitates the check of self-consistency. Moreover, these photochemical indicators can be used to assess the correlation between $\mathrm{O}_{3}$ concentration and the degree of aging for an air mass.

\section{RESULTS}

In total, 107 profiles were obtained by the tethersonde system during the field campaign. Fig. 3 shows the time series of ozone concentrations at this study site (Caotun) and .Taiwan EPA station (Dali) in August 2002. The $\mathrm{O}_{3}$ data display typical diurnal patterns, indicating that the concentration was minimal in the early morning, mainly owing to the reaction with NO and dry deposition during the nighttime, and peaked around noon due to daytime photochemical reactions, advection and vertical mixing.

During Aug. $17^{\text {th }}-20^{\text {th }}$ (as indicated by rectangle $\mathrm{A}$ in Fig. 3), the ozone concentration was higher than that during Aug. $23^{\text {rd }}-26^{\text {th }}$ (as indicated by rectangle $\mathrm{B}$ in Fig. 3). At the study site, the mean daily maximum ozone concentration achieved $82 \mathrm{ppb}$ during Aug. $17^{\text {th }}-20^{\text {th }}$, but it was only $57 \mathrm{ppb}$ during Aug. $23^{\text {rd }}-26^{\text {th }}$. At Dali station, the mean daily maximum ozone concentration was $74 \mathrm{ppb}$ during Aug. $17^{\text {th }}-20^{\text {th }}$; this value was also higher than that at $59 \mathrm{ppb}$ during Aug. $23^{\text {rd }}$ $26^{\text {th }}$. Therefore, the period A (Aug. $17^{\text {th }}-20^{\text {th }}$ ) is denoted as episodes, while the period $\mathrm{B}$ (Aug. $23^{\text {rd }}-26^{\text {th }}$ ) is denoted as non-episodes. These two periods will be analyzed for more details.

\section{Backwards Trajectory}

The backwards trajectory involved the route and sources of the polluting air mass, to determine whether that air mass is polluted by local emissions or influenced by external pollution sources and transmission. The GTx was used in the backward trajectory simulation, which used the field site (Caotun) as the receptor. The GTx inversely estimated meteorological data at each trajectory point, whereas the tendency of the trajectory changed in response to the wind field and topographic data for the location.

Figs. 4 and 5 show the distribution map of the backward trajectories and the contribution of PM, and it was categorized as ozone episode (Aug. 17 $7^{\text {th }}-20^{\text {th }}$ ) and non-episode period (Aug. $23^{\text {rd }}-26^{\text {th }}$ ). A clear difference existed in the distribution of the trajectory and contribution by each emission source. During the episode period, the trajectory distribution of air mass had a clear sea-land breeze mechanism with a relatively slow wind speed, which indicated that the air mass mainly got in through the western coastal area (i.e. Zhangbin industrial district) and then entered the study site (Caotun) after circling at the inland 

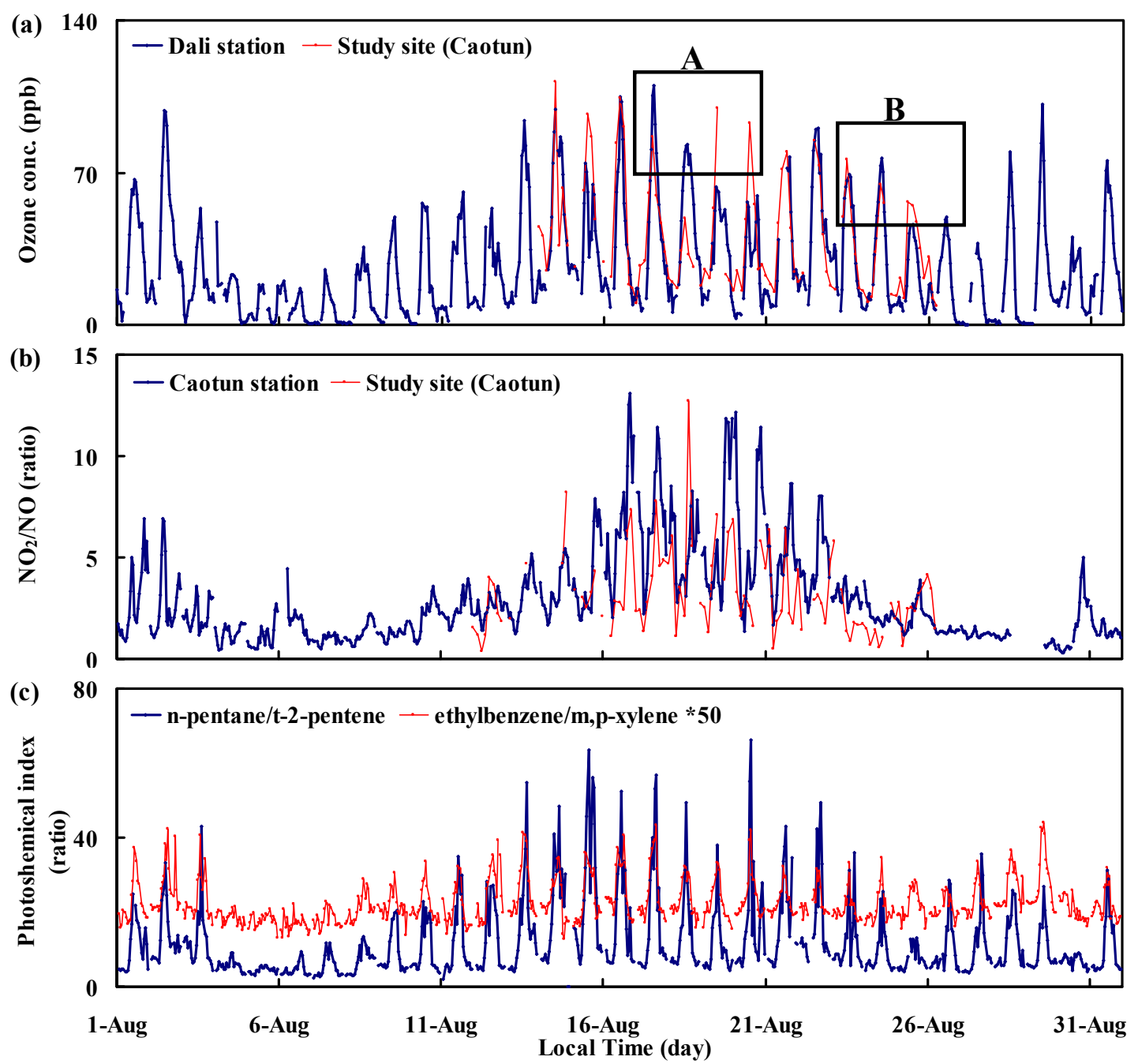

Fig. 3. Relationship between photochemical indices and ozone concentration in August 2002: (a) Time series of ozone concentrations at this study site (Caotun, red line) and Taiwan EPA station (Dali, blue line), where the rectangles A and B denote the periods of the ozone episode days and non-episode days, respectively, for further analysis. (b) the ratio of $\mathrm{NO}_{2} / \mathrm{NO}$ at the study site and Caotun station, and (c) the ratios of ethylbenzene/m,p-xylene and n-pentane/t-2-pentene measured at the Caotun PAMS.

(Fig. 4). Due to the relatively long route and slow speed during transmission, pollutants had additional time to react, easily producing secondary pollutants. Therefore, the concentrations of $\mathrm{O}_{3}$ and $\mathrm{PM}$ were higher during the ozone episode period than during the non-episode period (Figs. 4 and 5). Compared with the distribution of trajectories and PM contribution, the major pollution sources were located in the western coastal area, which includes central Taiwan and Zhanghua coastal areas whose emission sources significantly contributed to the receptors.

During the non-episode period, the trajectory distribution clearly differed from 

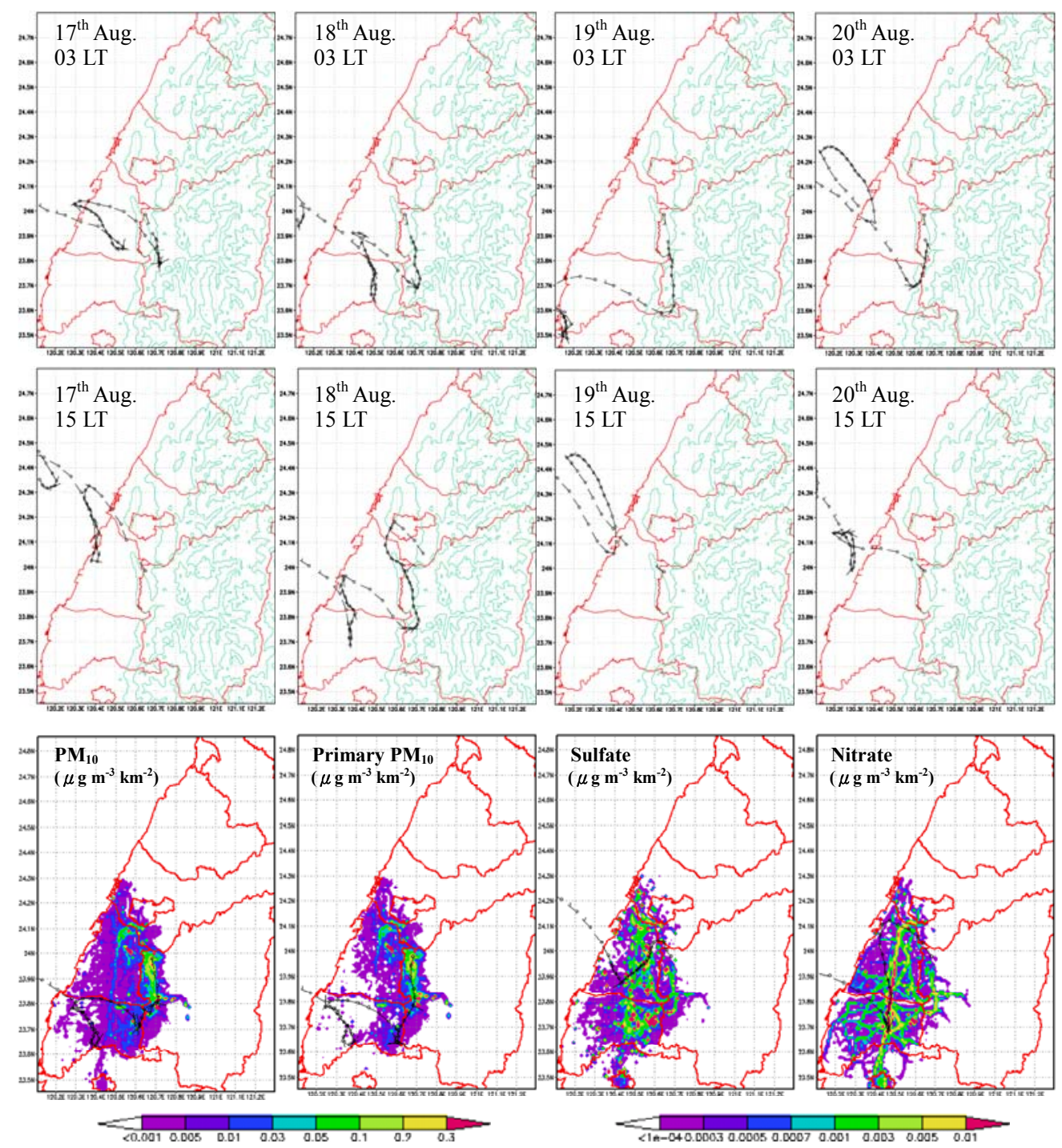

Fig. 4. Backward trajectories during ozone episode days (Aug. $17^{\text {th }}-20^{\text {th }}, 2002$ ) at nighttime (03 LT) (top panels) and daytime (15 LT) (middle panels), and the contributed concentrations of PM (PM 10 , primary $\mathrm{PM}_{10}, \mathrm{SO}_{4}^{2-}$ and $\mathrm{NO}_{3}^{-}$) on Aug. $17^{\text {th }}, 2002$ (bottom panels)

that during the episode period, and trajectory wind speed was faster, subsequently accelerating the air mass movement (Fig. 5). Most routes of the air mass were from south to north, and moved inland without touching the pollution sources in coastal areas; thus, the contribution of pollutants to this study site (Caotun) converged in inland areas. The emissions of pollutants were relatively small in inland areas; thus, the corresponding contribution was also relatively small. The concentrations of secondary pollutants $\mathrm{CO}_{3}$ and PM) during the non-episode period were comparatively low than those during the episode period.

\section{$\mathrm{PM}_{2.5}$ Observations}

The time periods for the particulate sampling were divided into daytime (08-20 LT) and nighttime (20-08 LT). Except for the 


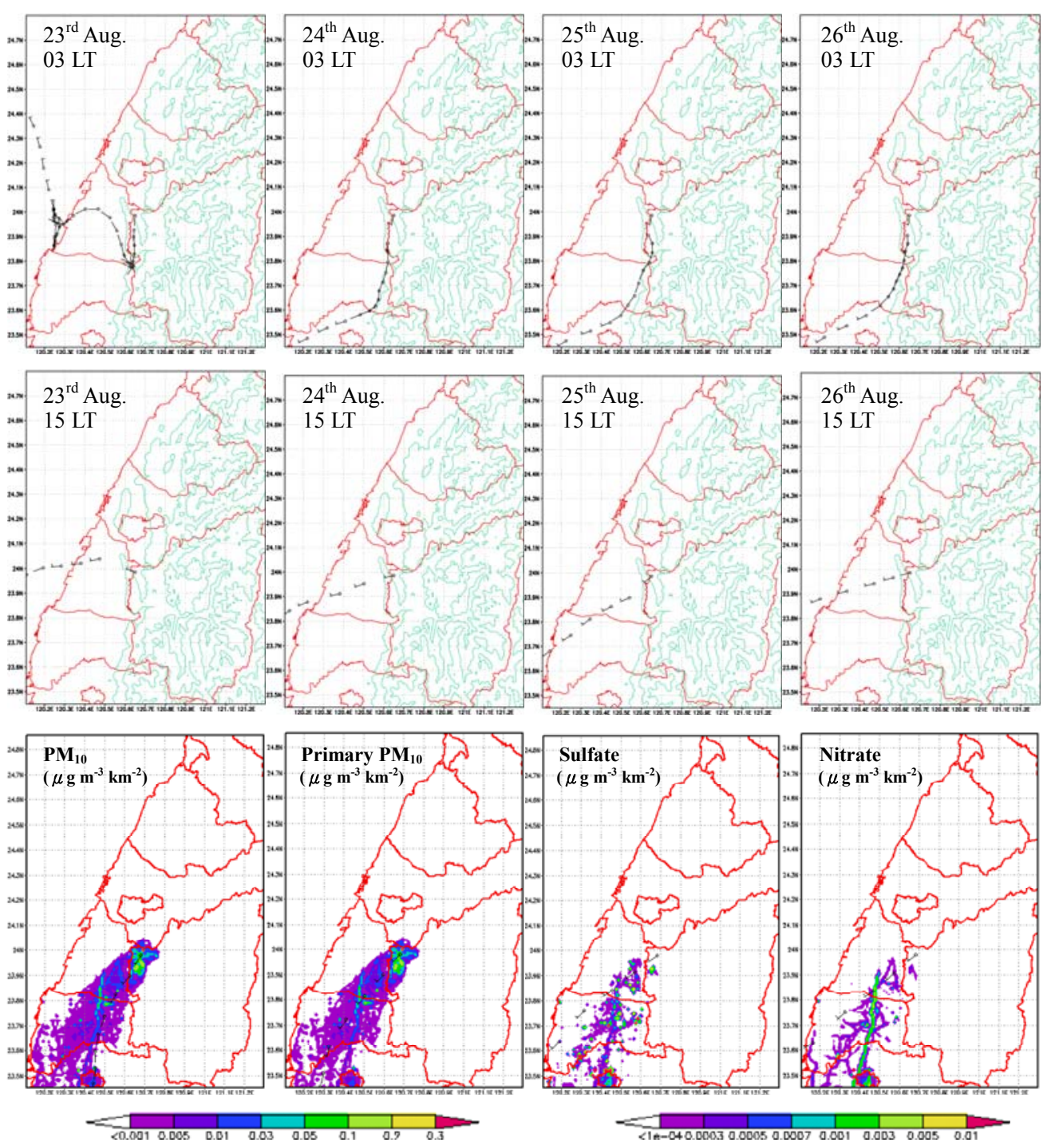

Fig. 5. Same as Fig. 4 but for during non-episode days (Aug. $23^{\text {rd }}-26^{\text {th }}, 2002$ ) at nighttime (03 LT) (top panels) and daytime (15 LT) (middle panels), and the contributed concentrations of PM (PM 10 , primary $\mathrm{PM}_{10}, \mathrm{SO}_{4}^{2-}$ and $\mathrm{NO}_{3}^{-}$) on Aug. $25^{\text {th }}, 2002$ (bottom panels).

raining day, there were seven days' data (twelve samples) were obtained during the field campaign. There were four days belonged to $\mathrm{O}_{3}$ episodes and the other three days belong to non-episodes. Table 2 presents the concentrations of $\mathrm{PM}_{2.5}$, the $\mathrm{NO}_{3}^{-}, \mathrm{SO}_{4}^{2-}$ and $\mathrm{NH}_{4}^{+}$in $\mathrm{PM}_{2.5}$, and the gaseous pollutant's concentration of $\mathrm{HNO}_{3}, \mathrm{HNO}_{2}$ and $\mathrm{NH}_{3}$ measured at NCHU during the field campaign. As for the neutralization ratio (N.R.) was employed to indicate the degree of neutralization of aerosol acidity. N.R. can be expressed as the ratio of $\mathrm{NH}_{4}^{+}$concentration (in neq $/ \mathrm{m}^{3}$ ) to the sum of the non-sea-salt sulfate and the nitrate (in neq $/ \mathrm{m}^{3}$ ). Most values of N.R. from ozone episode days and nonozone episode days were 1.0, which means the aerosol particles were neutral.

Fig. 6 presents mean $\mathrm{PM}_{2.5}$ and gaseous episode days to non-episode days. The episode 
Table 2. Concentrations of atmospheric aerosols and gaseous pollutants during August 16-26, 2002.

Date

\begin{tabular}{l|l} 
High Ozone episode day & Non-Ozone episode day
\end{tabular}

8/16D 8/18D 8/20D 8/16N 8/19N 8/20N 8/24D 8/25D 8/26D 8/24N 8/25N 8/26N

\begin{tabular}{|c|c|c|c|c|c|c|c|c|c|c|c|c|c|}
\hline $\mathrm{PM}_{2.5}$ & $\left(\mu \mathrm{g} / \mathrm{m}^{3}\right)^{\mathrm{a}}$ & 48.9 & 76.3 & 30.8 & 45.4 & 49 & 49.8 & 38.4 & 35.6 & 26.1 & 21.7 & 37 & 28.4 \\
\hline $\mathrm{SO}_{4}^{2-}$ & $\left(\mu \mathrm{g} / \mathrm{m}^{3}\right)^{\mathrm{a}}$ & 11.0 & 21.2 & 9.8 & 13.3 & 9.5 & 12.8 & 10.3 & 6.9 & 3.9 & 7.1 & 6.5 & 2.4 \\
\hline $\mathrm{NO}_{3}^{-}$ & $\left(\mu \mathrm{g} / \mathrm{m}^{3}\right)^{\mathrm{a}}$ & 8.3 & 12.9 & 3.5 & 8.8 & 9.9 & 11.5 & 2.5 & 1.9 & 1.5 & 1.6 & 4.2 & 1.4 \\
\hline $\mathrm{NH}_{4}^{+}$ & $\left(\mu \mathrm{g} / \mathrm{m}^{3}\right)^{\mathrm{a}}$ & 6.7 & 11.0 & 4.8 & 7.4 & 6.9 & 8.5 & 4.7 & 3.4 & 1.7 & 3.2 & 3.8 & 1.2 \\
\hline $\mathrm{HNO}_{3}$ & $\left(\mu \mathrm{g} / \mathrm{m}^{3}\right)^{\mathrm{a}}$ & 9.2 & 8.5 & 7.6 & 1.4 & 0.8 & 1.2 & 2.0 & 2.1 & 2.9 & 0.7 & 1.1 & 0.6 \\
\hline $\mathrm{HNO}_{2}$ & $\left(\mu \mathrm{g} / \mathrm{m}^{3}\right)^{\mathrm{a}}$ & 1.0 & 0.9 & 0.7 & 3.0 & 3.4 & 3.5 & 0.8 & 0.4 & 0.9 & 1.6 & 1.8 & 3.2 \\
\hline $\mathrm{NH}_{3}$ & $\left(\mu \mathrm{g} / \mathrm{m}^{3}\right)^{\mathrm{a}}$ & 10.1 & 10.4 & 8.6 & 15.5 & 15.3 & 13.2 & 11.2 & 11.8 & 9.5 & 4.2 & 14.5 & 17.5 \\
\hline $\mathrm{NO}_{2}$ & $\left(\mu \mathrm{g} / \mathrm{m}^{3}\right)^{\mathrm{a}}$ & 34.4 & 21.1 & 47.5 & 33.6 & 37.6 & 32.6 & 24.3 & 17.7 & 28.6 & 19.9 & 29.5 & 36.9 \\
\hline $\mathrm{SO}_{2}$ & $\left(\mu \mathrm{g} / \mathrm{m}^{3}\right)^{\mathrm{a}}$ & 4.3 & 2.3 & 6.4 & 1.9 & 2.4 & 1.7 & 9.3 & 3.5 & 9.1 & 4.0 & 6.2 & 9.1 \\
\hline \multicolumn{2}{|c|}{ NR } & 1.0 & 1.0 & 1.0 & 1.0 & 1.1 & 1.1 & 1.0 & 1.1 & 1.0 & 1.0 & 1.1 & 1.0 \\
\hline
\end{tabular}

N.R. (neutralization ratio) $=\mathrm{NH}_{4}^{+} /\left(\mathrm{SO}_{4}^{2-}+\mathrm{NO}_{3}^{-}\right)$, unit of each species is neq $/ \mathrm{m}^{3}$.

D: Daytime (08 LT to 20 LT); N: Nighttime (20 LT to 08 LT in the next day)

a: NCHU data; b: Dali station data

No sample for $8 / 17 \mathrm{D}$ and $\mathrm{N}, 8 / 18 \mathrm{~N}, 8 / 21 \sim 8 / 23 \mathrm{D}$ and $\mathrm{N}$ was due to the raining weather.

(a) DayTime ( 08 AM. 08 PM. )

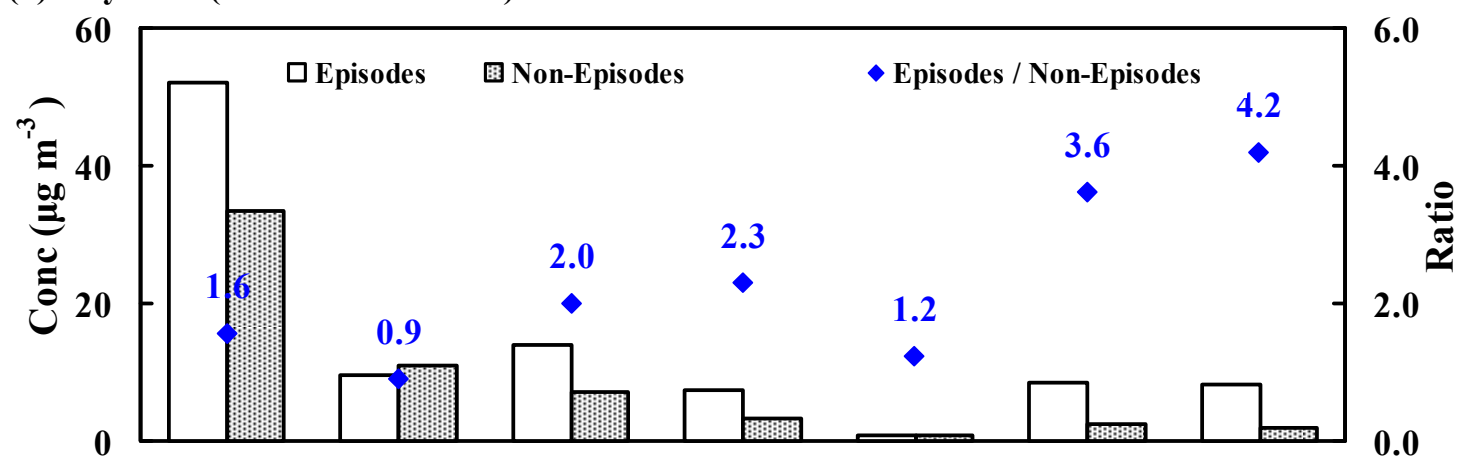

(b) NightTime ( 08 PM. 08 AM. )

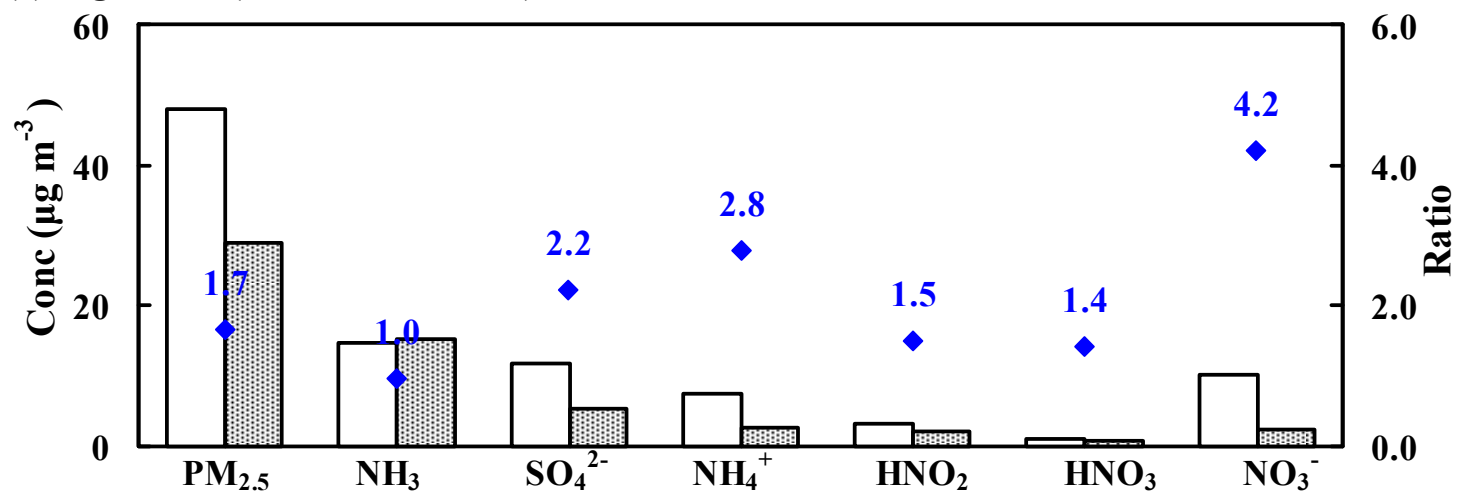

Fig. 6. Concentrations of $\mathrm{PM}_{2.5}$ and gaseous pollutants and their ratio on ozone episode days and nonepisode days. (a) daytime, (b) nighttime. 
pollutant concentrations and the ratio of $\mathrm{O}_{3}$ days had higher concentrations of $\mathrm{PM}_{2.5}, \mathrm{SO}_{4}^{2-}$, $\mathrm{NO}_{3}^{-}$and $\mathrm{NH}_{4}^{+}$than did the non-episode days. Both in the daytime and nighttime, the $\mathrm{O}_{3}$ episodes values of $\mathrm{PM}_{2.5}, \mathrm{SO}_{4}^{2-}, \mathrm{NO}_{3}^{-}$and $\mathrm{NH}_{4}^{+}$were approximately 1.6 times, 2 times, 4.2 times and 2.5 times, respectively, than those during non-episodes. The gases of $\mathrm{HNO}_{3}$ and $\mathrm{HNO}_{2}$ gases on ozone episode days were approximately 3.6 times and 1.2 times more plentiful, respectively, on non-episode days in the daytime. However, the ammonia concentration was not different between on ozone episode days and non-episode days. Furthermore, these data show that the rate of $\mathrm{NO}_{3}^{-}$formation was faster than that of $\mathrm{SO}_{4}^{2-}$ formation on ozone episode days.

\section{Speciated VOCs Observations}

In this study, the four compounds (ethylbenzene, m,p-xylene, n-pentane and t-2pentene) used for the photochemical indices are used to assess the correlation between ozone concentrations and aged air mass. Fig. 7(a) shows the time series of ethylbenzene and m,p-xylene concentrations measured by the Caotun PAMS during August 2002. The abundance of two species are strongly correlated (correlation coefficient, $r=0.95$ ), due to their common origin and modulation by meteorological parameters. Similarly, the correlation of $n$-pentane and $\mathrm{t}$-2-pentene is also significant $(\mathrm{r}=0.60$, Fig. 7(b)). These VOCs are largely traffic-related whose abundance profile has a pattern similar to that of the traffic flow. There analytical results indicate that the origins these four compounds are mainly from vehicles and be well mixed after being transporting to the Caotun study site. Consequently high concentrations of four compounds were observed during the morning and evening rush hours.

\section{DISCUSSION}

\section{Correlation between Ozone and PM Concentrations}

The $\mathrm{OH}$ radical and $\mathrm{NO}_{2}$ creating $\mathrm{HNO}_{3}$ was the main reaction eliminating the $\mathrm{OH}$ radical in the troposphere (Eq. (6)). $\mathrm{HNO}_{3}$ in the atmosphere was finally eliminated by wet deposition or absorbed by the aerosol (Huebert and Robert, 1985; Derwent et al., 1988; Dentener, 1993, Cox, 1988).

$$
\mathrm{OH} \cdot+\mathrm{NO}_{2} \longrightarrow \mathrm{HNO}_{3}
$$

The $\mathrm{HNO}_{2}$ was generated by the reaction of $\mathrm{OH}$ radicals with $\mathrm{NO}$ (Eq. (7)); however, when sunshine was sufficient, $\mathrm{HNO}_{2}$ very easily broke down into $\mathrm{OH}$ radical and $\mathrm{NO}$ via photolysis (Eq. (8)). The traffic flow during afternoon rush hour emitted significant amounts of NO and hydrocarbons, which react with high concentrations of $\mathrm{OH}$ radicals to produce $\mathrm{HNO}_{2}$.

$$
\begin{aligned}
& \mathrm{OH} \cdot+\mathrm{NO} \longrightarrow \mathrm{HNO}_{2} \\
& \mathrm{HNO}_{2} \stackrel{\text { sunlight }}{\longrightarrow} \mathrm{OH} \cdot+\mathrm{NO}
\end{aligned}
$$

During the night, $\mathrm{HNO}_{2}$ could not conduct photolysis reaction, while Eqs. (9) and (10) were still going on to produce $\mathrm{HNO}_{2}$, which 

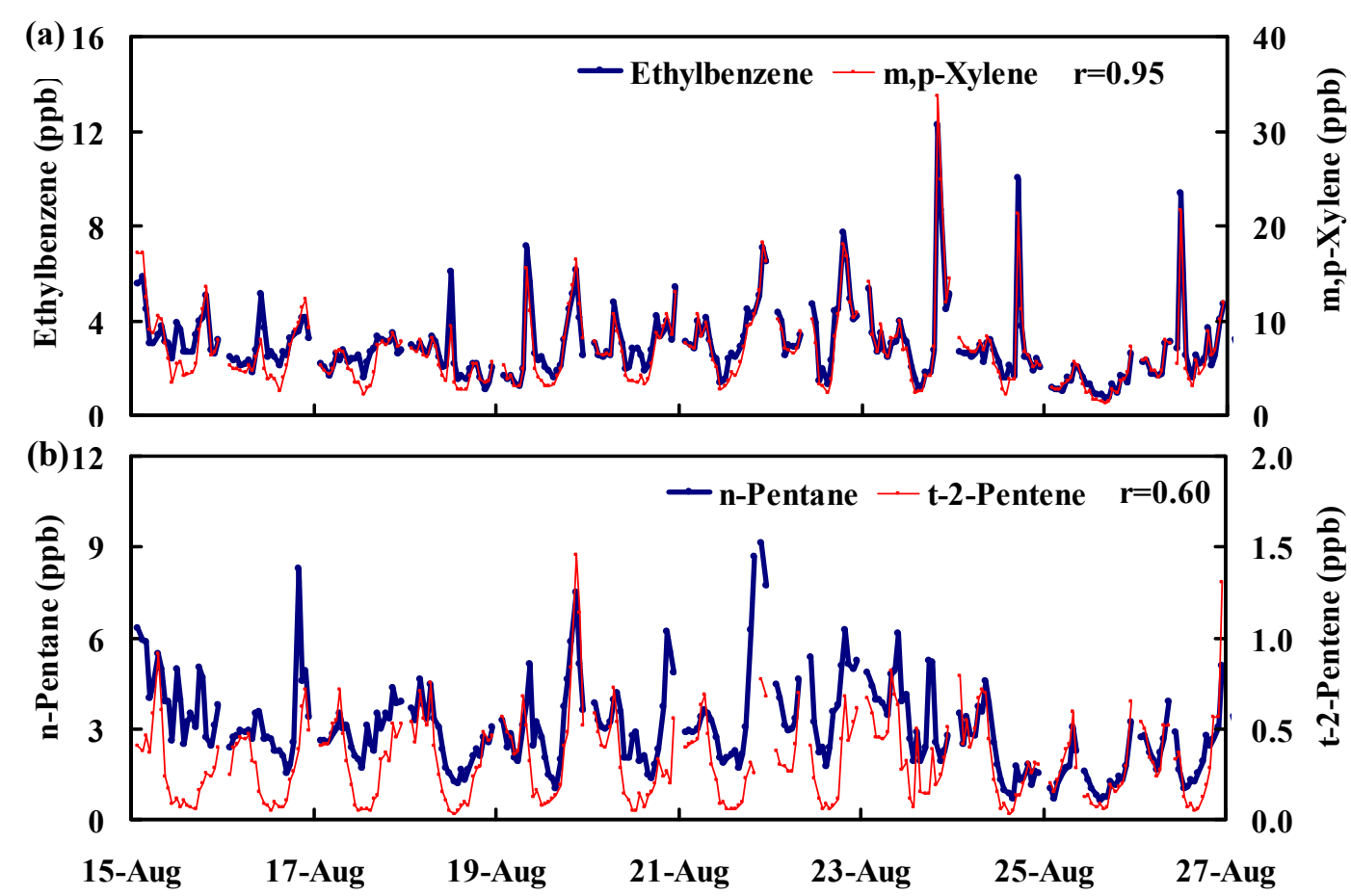

Fig. 7. Time series of concentrations of (a) ethylbenzene and xylene; (b) n-pentane and t-2-pentene from the Caotun PAMS in 2002, where $r$ is the correlation coefficient of the concentrations between the two compounds in each panel.

resulted in the accumulation of $\mathrm{HNO}_{2}$. Moreover, a positive correlation existed between the $\mathrm{HNO}_{2}$ and $\mathrm{PM}_{2.5}$ concentrations (Lin et al., 2006).

$$
\begin{aligned}
& 2 \mathrm{NO}_{2}+\mathrm{H}_{2} \mathrm{O} \longrightarrow \mathrm{HNO}_{3}+\mathrm{HNO}_{2} \\
& \mathrm{NO}+\mathrm{NO}_{2}+\mathrm{H}_{2} \mathrm{O} \longrightarrow 2 \mathrm{HNO}_{2}
\end{aligned}
$$

According to the above-mentioned conditions, $\mathrm{HNO}_{2}$ was produced and accumulated during the previous night, and the photolysis reaction began at sunrise, resulting in rapid growth of $\mathrm{OH}$ radicals in the atmosphere, consequently initiating the following photochemical reactions that produced $\mathrm{O}_{3}$ and $\mathrm{HNO}_{3}$. The daytime ozone concentration and $\mathrm{HNO}_{2}$ concentration during the previous nigh were strongly correlated (positive correlation, $\mathrm{R}^{2}=0.66$, Fig. $8(\mathrm{~b})$ ). Additionally, $\mathrm{HNO}_{3}$ was also produced by the reaction of $\mathrm{OH}$ radicals with $\mathrm{NO}_{2}$ (Eq. (6)) and was increased by photochemical reactions on ozone episode days. Fig. 8(a) indicates that the ozone and $\mathrm{HNO}_{3}$ concentrations during daytime were strongly correlated (positive correlation, $\left.\mathrm{R}^{2}=0.67\right)$. This analytical result demonstrates that daytime ozone concentrations accompany $\mathrm{HNO}_{3}$ concentrations and depend on the $\mathrm{HNO}_{2}$ concentration of the previous night.

\section{Conversion Ratio}

The conversion ratio of sulfur $\left(\mathrm{F}_{\mathrm{S}}\right)$ and nitrogen $\left(\mathrm{F}_{\mathrm{N}}\right)$ can describe the degree to which $\mathrm{SO}_{2}$ or $\mathrm{NO}_{2}$ exists in the atmosphere as 
(a)

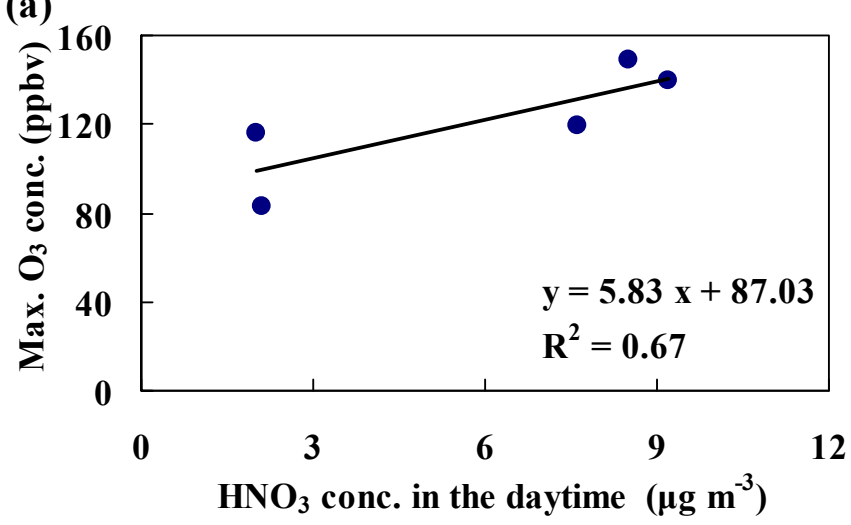

(b)

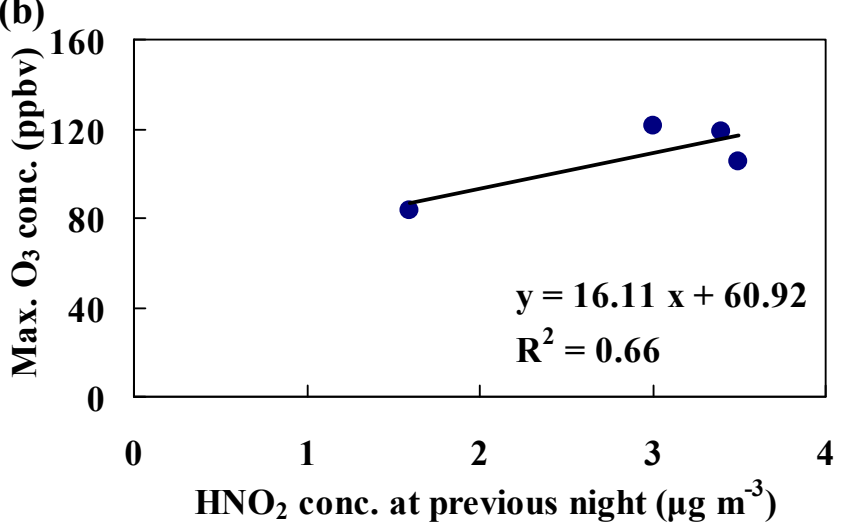

Fig. 8. Correlation between the maximum ozone concentration in the daytime and the concentrations of gaseous pollutants. (a) $\mathrm{HNO}_{3}$ in the daytime, (b) $\mathrm{HNO}_{2}$ on the previous night.

secondary pollutants. Eqs. (11) and (12) are as follows (Kadowaki, 1986; Khoder, 2002):

$$
\begin{aligned}
& \mathrm{F}_{\mathrm{S}}=\frac{\mathrm{PSO}_{4}^{2-}}{\mathrm{SO}_{2}+\mathrm{PSO}_{4}^{2-}} \\
& \mathrm{F}_{\mathrm{N}}=\frac{\mathrm{GNO}_{3}^{-}+\mathrm{PNO}_{3}^{-}}{\mathrm{NO}_{2}+\mathrm{GNO}_{3}^{-}+\mathrm{PNO}_{3}^{-}}
\end{aligned}
$$

where $\mathrm{PSO}_{4}^{2-}$ is the $\mathrm{SO}_{2}$ concentration in particulate sulfate with the unit of $\mu \mathrm{g} / \mathrm{m}^{3}$. $\mathrm{GNO}_{3}^{-}$and $\mathrm{PNO}_{3}^{-}$represent the $\mathrm{NO}_{2}$ concentrations in gaseous nitric acid and particulate nitrate with the unit of $\mu \mathrm{g} / \mathrm{m}^{3}$.

Fig. 9 presents the $\mathrm{O}_{3}$ concentration, $\mathrm{F}_{\mathrm{S}}$ and $F_{N}$ in the daytime and nighttime during the ozone episodes and non-episodes. Analytical results show that the $\mathrm{F}_{\mathrm{S}}, \mathrm{F}_{\mathrm{N}}$ and mean $\mathrm{O}_{3}$ concentrations in central Taiwan were $60-90 \%$, 10-30\% and 28-106 ppb, respectively, during the ozone episodes, but only $20-60 \%, 3-10 \%$ and 13-67 ppb, respectively, during nonepisodes

Moreover, regardless of time, the $\mathrm{F}_{\mathrm{S}}, \mathrm{F}_{\mathrm{N}}$ and
$\mathrm{O}_{3}$ concentrations during ozone episodes were higher than those during non-episodes. This phenomenon indicates that pollutants in air masses have a long reaction time during ozone episodes, resulting in the formation of substantial amounts of secondary pollutants. A strong correlation exists between the ozone concentration and the $\mathrm{Fs}$ and $\mathrm{F}_{\mathrm{N}}$ in the daytime; the determinations of correlation $\left(\mathrm{R}^{2}\right)$ are 0.74 and 0.58 , respectively (Figs. 10(a) and 10(b)). This indirectly indicates that the air mass is aged during ozone episodes. This analytical result indicates that the ozone concentration is directly proportional to the aging degree of the air mass.

\section{Correlation between Ozone Concentration and Aged Air Masses}

Ozone is one of the major products of photochemical reactions of VOCs in the presence of $\mathrm{NO}_{\mathrm{x}}$. Nevertheless, local ozone levels do not directly link to VOC abundance, as ozone is a secondary pollutant, and the complexity of photochemistry and meteorology combined perplexes such linkage. 

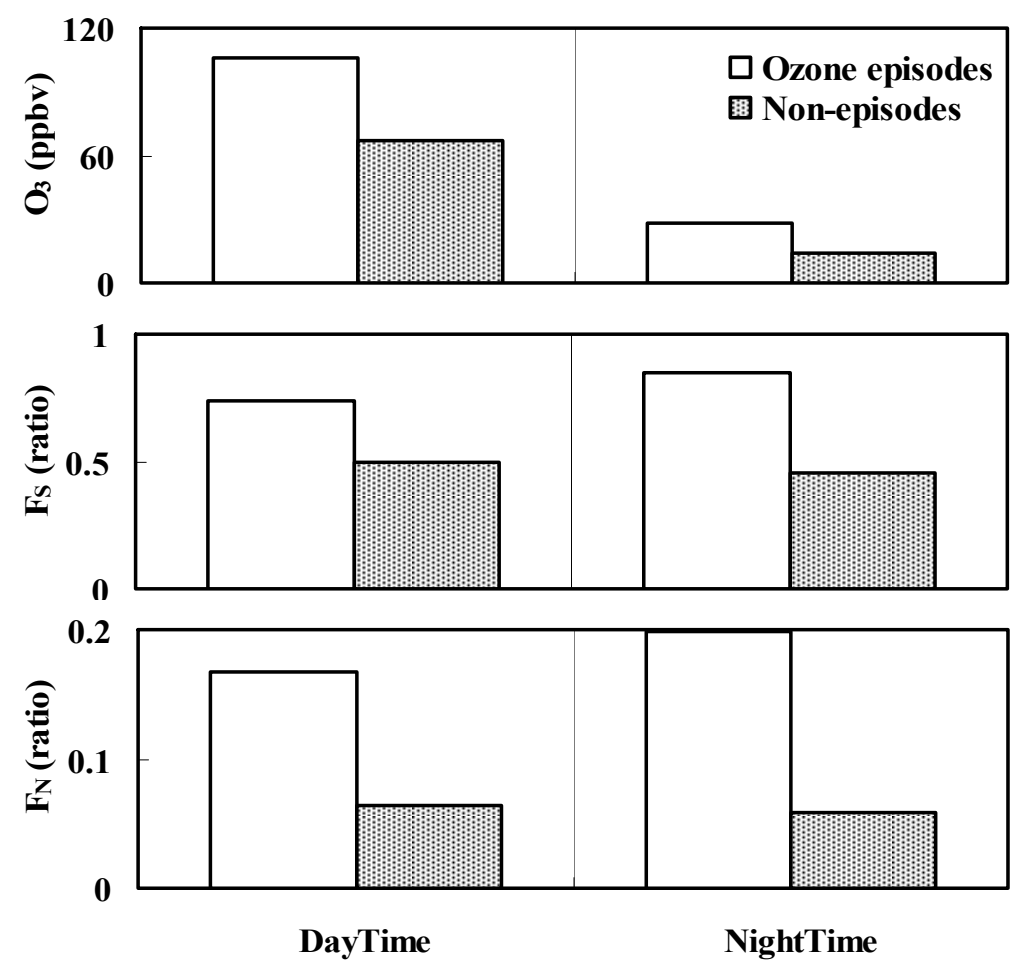

Fig. 9. Composites of the sulfur conversion ratio $(F s)$, nitrogen conversion ratio $\left(F_{N}\right)$ and ozone concentration in the daytime and nighttime.
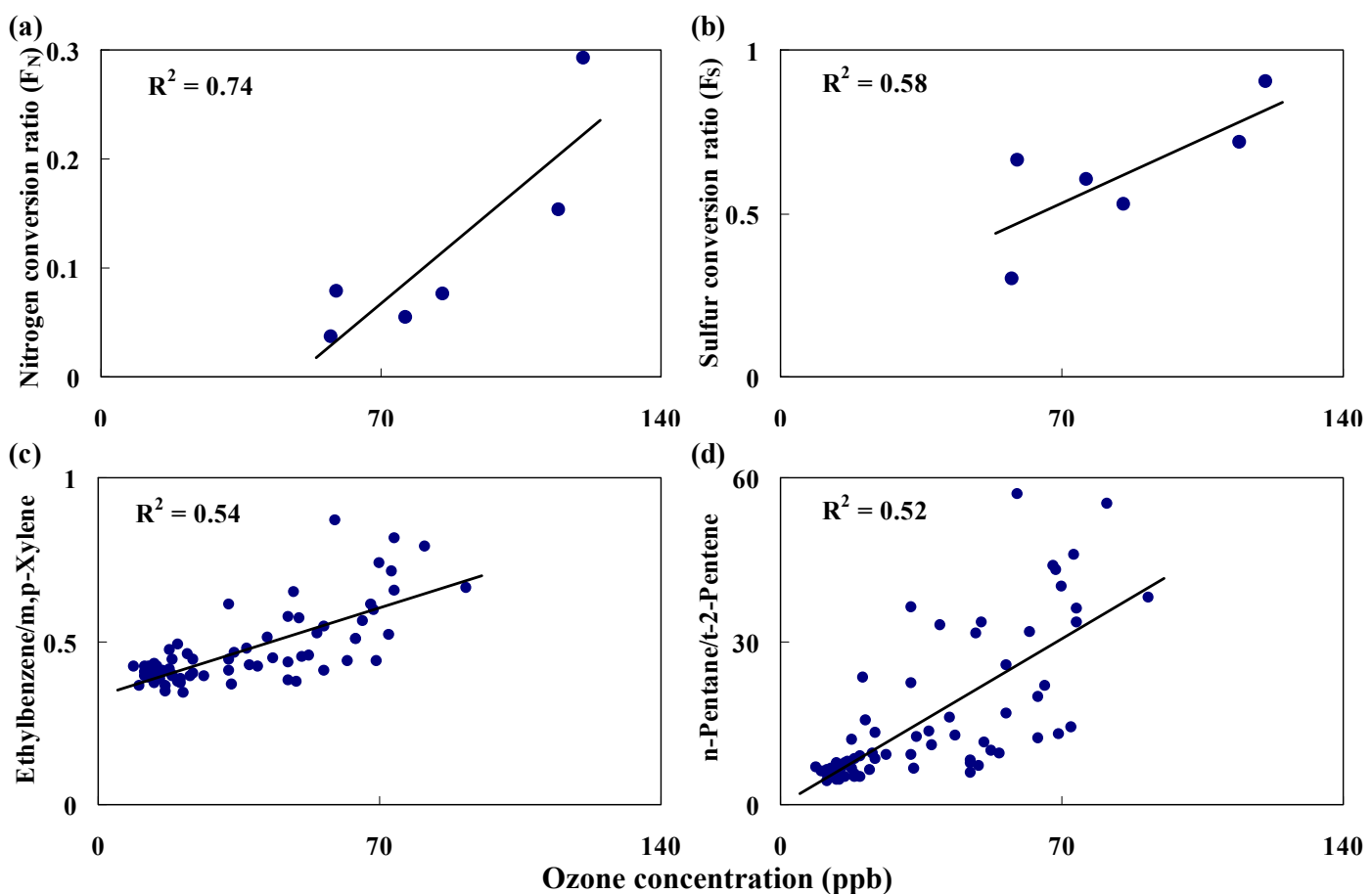

Fig. 10. Correlation between the ozone concentration and (a) the sulfur conversion ratio and (b) nitrogen conversion ratio in the daytime; (c) ethylbenzene/m,p-xylene and (d) pentane/t-2-pentene ratio during the field campaign period. 
The photochemical process can be followed by examining ratios of a compound pair with a common origin but considerable difference in reactivity. By taking the ratio of a less reactive species to a more reactive species, the ratio tends to be constant in the source area dominated by fresh emissions, but could increase as an air parcel is subject to photochemical process during transport as the more reactive species decreases more rapidly. Continuous measurement with adequate time resolution at a receptor site is particularly suited for studying the effect of photochemistry by registration of the dynamic "aging" process. In this study, the ratios ethylbenzene/m,p-xylene and n-pentane/t-2pentene were determined to identify the degree of photochemical reactions, or the socalled "age" of an air mass. By taking the ratio of these two VOC pairs, the age of an air mass can be determined, which in principle should be moderately correlated with ozone concentration within the same air mass (Chang et al., 2006; Tsai et al., 2008; Wang et al., 2008).

This comparison between the photochemical index and $\mathrm{O}_{3}$ concentration shows that the strength of the correlation fluctuates was strong (Figs. 3 and 10); thus, the photochemical indices are used to discuss the relationship between ozone concentration and air mass age. In addition, Fig. 3(b) shows the ratio of $\mathrm{NO}_{2} / \mathrm{NO}$ from this field campaign and Caotun station. The method for nitrogen oxide is similar to the photochemical index. High ratios indicate that air masses are depleted in reactive compounds (denominators), which translates into photochemical aged air masses and, thus, the amount of ozone produced increases. Low ratios produce an opposite result. These two ratio pairs repeatedly cycle, with maximum values existing around noon and minimum values occurring at night (Figs. 3 and 11). The fact that the two pairs of patterns are extremely coherent across the entire month shows that the data are self-consistent and are of a high quality. The ozone concentration and ethylbenzene/m,p-xylene are strongly correlated with the determination of correlation coefficients of 0.54 (Fig. 10(c)). Furthermore, the ozone concentration and npentane/t-2-pentene are also strongly correlated $\left(\mathrm{R}^{2}=0.52\right.$, Fig. $\left.10(\mathrm{~d})\right)$. Thus, we suggest a common cause: photochemistry drives the diurnal cycles of the ratios and ozone concentration.

The daily cycle of the photochemical index for the Chonlun and Caotun PAMS and the two sets of ratios consistently peak in early afternoon, mostly between 12LT and $15 \mathrm{LT}$, and coincide in time and magnitude with ozone cycles (Figs. 3 and 11), demonstrating the cause-and-effect relationship between precursors and ozone within the same air mass. The fact that VOCs ratio cycles are nearly synchronous with ozone cycles, even though these two measurements sites are apart, suggests that VOCs data and ozone data were representative of a large area. Furthermore, the highly consistent result proves that using VOC ratios as indicators of air mass age is both theoretically and practically sound (Figs. 3 and 10). 

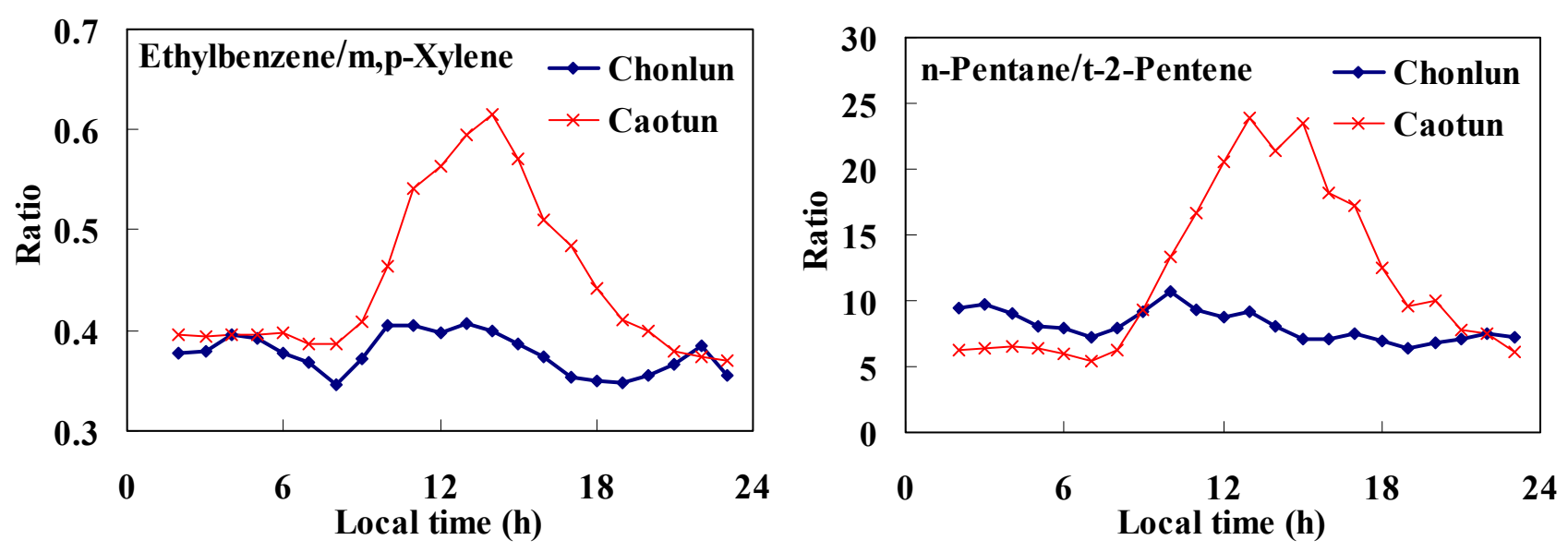

Fig. 11. Composite hourly ratios of ethylbenzene/m,p-xylene and pentane/t-2-pentene measured by the Chonglun and Caotun PAMS during entire August 2002.

Using the concentration ratio of ethylbenzene/m,p-xylene as an example, these two species move with the air mass downwind, and the photochemical reactions occur during this movement. Because the life cycle of $\mathrm{m}, \mathrm{p}$ xylene is shorter than that of ethylbenzene, the concentration of m,p-xylene would decrease faster than that of ethylbenzene; thus, the ratio increases as the transmission distance increases. The ratio at Caotun is higher than that at Chunlun (Fig. 11), which corresponds to the distributed positions of each station, where Chunlun is situated upwind and Caotun downwind. This phenomenon indicates that the air mass in the downwind is older than the air mass upwind.

\section{CONCLUSIONS}

In this study site (Caotun), it only has a few emission sources of ozone precursor; however, ozone episodes occurred, likely because of the high amount of reactive compound entering the Caotun area via transmission. The trajectory distribution result indicates that the air mass mainly entered study site through the western coastal area and circled at the inland (sea-land breeze mechanism) during the ozone episodes. Due to the relatively long route and slow speed during transmission, the highly reactive compound had long reaction time to react with $\mathrm{NO}_{\mathrm{x}}$. Therefore, a high ozone concentration was produced.

Analytical results demonstrate that $\mathrm{HNO}_{2}$ accumulated during the previous night, leading to photolysis and photochemical reactions that produced $\mathrm{O}_{3}$ at sunrise. The $\mathrm{O}_{3}$ concentrations increased to accompany $\mathrm{HNO}_{3}$ concentrations by photochemical reactions in the daytime. Gaseous $\mathrm{PM}_{2.5}$ and secondary aerosol during the ozone episodes had higher concentrations than during the non-episodes. Furthermore, the sulfur conversion ratio increased as the ozone concentration increases, as did the nitrogen conversion ratio.

Six compounds (ethylbenzene, m,p-xylene, n-pentane, $\mathrm{t}$-2-pentene, $\mathrm{NO}$ and $\mathrm{NO}_{2}$ ) are used for the photochemical index. The 
photochemical indices (ethylbenzene/m,pxylene, n-pentane/t-2-pentene and $\mathrm{NO}_{2} / \mathrm{NO}$ ) peaked consistently in the early afternoon and coincide in time and magnitude with ozone cycles, manifesting the cause-and-effect relationship between precursors and ozone within the same air mass. Furthermore, this highly consistent result proves that using VOCs and $\mathrm{NO}_{2} / \mathrm{NO}$ ratios as aging indicators for an air mass is both theoretically and practically sound.

\section{ACKNOWLEDGMENTS}

The authors are grateful for financial support from the National Science Council, Taiwan, under the contracts NSC-91-EPA-Z005-004, NSC-92-2211-E-005-023, NSC-932211-E-005-006, NSC-94-2211-E-005-039, NSC 95-EPA-Z-005-001 and NSC 95-2111M-005-001. Thanks to Dr. Arumugam Alagesan, Dr. Andrew Keats, Dr. Ted Knoy Dr. Chien-Lung Chen for proof reading. We are also grateful to Pei-Hsuan Kuo, ChuenLiang Horng, Ding-Cang Kuo, Mei-Chun Kuo. Jun-Nan Kuo, Co-Zi Yen and Yu-Chi Kuo for their assistance with the tethersonde operation.

\section{REFERENCES}

Begum, B.A., Biswas, S.K. and Hopke, P.K. (2007). Source Apportionment of Air Particulate Matter by Chemical Mass Balance (CMB) and Comparison with Positive Matrix Factorization (PMF) Mmodel. Aerosol Air Qual. Res. 7: 446468.
Carter, W.P.L. (1994). Development of Ozone Reactivity Scales for Volatile Organic Compounds. J. Air Waste Manage. Assoc. 44: 881-899.

Chang, C.C., Wang, J.L., Liu, S.C. and Lung, S.C.C. (2006). Assessment of Vehicular and Non-vehicular Contributions to Hydrocarbons Using Exclusive Vehicular Indicators. Atmos. Environ. 40: 6349-6361.

Chen,C.L., Tsuang, B.J., Tu, C.Y., Cheng, W.L. and Lin, M.D. (2002). Wintertime Vertical Profiles of Air Pollutants over a Suburban Area in Central Taiwan. Atmos. Environ. 36: 2049-2059.

Chio, C.P., Cheng, M.T. and Wang, C.F. (2004). Source Apportionment to $\mathrm{PM}_{10}$ in Different Air Quality Conditions for Taichung Urban and Costal Areas, Taiwan. Atmos. Environ. 38: 6893-6905.

Cox, D.D. (1988). Approximation of Least Squares Regression on Nested Subspaces. Ann. Statist. 16: 713-732.

CTCI, (2003). Update and Management for Air Pollution Emission Inventory and Estimation for Air Pollution Degradation of GNP. Report, Environmental Protection Administration-Taiwan, EPA-92-FA11-03D039 (in Chinese).

Dentener, F.J. and Crutzen, P.J. (1993). Reaction of $\mathrm{N}_{2} \mathrm{O}_{5}$ on Tropospheric Aerosols: Impact on the Global Distributions of $\mathrm{NO}_{\mathrm{x}}$, $\mathrm{O}_{3}$, and $\mathrm{OH}$. J. Geophys. Res. 98: 71497163.

Derwent, R.G., Hopper, S. and Metcalfe, S.E. (1988). Computer Modeling Studies of the Origins of the Acidity Deposited in Scotland. Atomic Energy Research 
Establishment. Report no. 13328.

Dubey, N. and Pervez, S. (2008). Investigation of Variation in Ambient $\mathrm{PM}_{10}$ Levels within an Urban-industrial Environment. Aerosol Air Qual. Res. 8: 54-64.

Environmental Protection Administration, Taiwan (EPA/Taiwan). (2003). Air Quality Annual Report Taiwan Area in 2002. EPA Publication GPN 2008400070, Taiwan Environmental Protection Administration, Taipei, p. 218.

Feichter, J., Kjelldtröm, E., Rodhe, H., Dentener, F., Lelieveld, J. and. Roelofs, G.J. (1996). Simulation of the Ttropospheric sSulfur Cycle in a Global Climate Model. Atmos. Environ. 30: 1693-1707.

Geyer, A., Ackermann, R., Dubois, R., Lohrmann, B., Müller, T. and Platt, U. (2001). Long-term Observation of Nitrate Radicals in the Continental Boundary Layer near Berlin. Atmos. Environ. 35: 3619-3631. Huebert, B.J. and Robert, C.H. (1985). The Dry Deposition of Nitric Acid to Grass. J. Geophys. Res. 90: 2085-2090.

Jenkin, M.E. and Clemitshaw, K.C. (2000). Ozone and other Secondary Photochemical Pollutants: Chemical Processes Governing Their Formation in the Planetary Boundary Layer. Atmos. Environ. 34: 2499-2527.

Kadowaki, S. (1986). On the Nature of Atmospheric Oxidation Processes of $\mathrm{SO}_{2}$ to Sulfate and of $\mathrm{NO}_{2}$ to Nitrate on the Basis of Diurnal Variations of Sulfate, Nitrate, and other Pollution in an Urban Area. Environ. Sci. Technol. 20: 1249-1253.

Khoder, M.I. (2002). Atmospheric Conversion of Sulfur Dioxide to Particulate Sulfate and
Nitrogen Dioxide to Particulate Nitrate and Gaseous Nitric Acid in an Urban Area. Chemosphere. 49: 675- 684.

Kobara H., Takeuchi, K. and Ibusuki, T. (2007). Effect of Relative Humidity on Aerosol Generation through Experiments at Low Concentrations of Gaseous Nitric Acid and Ammonia. Aerosol Air Qual. Res. 7: 193-204.

Kuo, Y.M., Hung, H.F. and Yang, T.T. (2007). Chemical Compositions of $\mathrm{PM}_{2.5}$ in Residential Homes of Southern Taiwan. Aerosol Air Qual. Res. 7: 403-416.

Lin, C.H., Wu, Y.L., Lai, C.H., Watson, J.G. and Chow, J.C. (2008). Air Quality Measurements from the Southern Particulate Matter Supersite in Taiwan. Aerosol Air Qual. Res. 8: 233-264.

Lin, Y.C., Cheng, M.T., Ting, W.Y. and. Yeh, C.R. (2006). Characteristics of Gaseous $\mathrm{HONO}, \mathrm{HNO}_{3}, \mathrm{NH}_{3}$ and Particulate Ammonium Nitrate in an Urban City of Central Taiwan. Atmos. Environ. 40: 47254733.

Logan, J. A. (1989). Ozone in Rural Areas of the United States. J. Geophys. Res. 94: 8511-8532.

Matsumoto, J., Imai, H., Kosugi, N. and Kajii, Y. (2005). In Situ Measurement of $\mathrm{N}_{2} \mathrm{O}_{5}$ in the Urban Atmosphere by Thermal Decomposition/Laser-Induced Fluorescence Technique. Atmos. Environ. 39: 6802-6811.

Matsumoto, K. and Tanaka, H. (1996). Formation and Dissociation of Atmospheric Particulate Nitrate and Chloride: an Approach Based on Phase Equilibrium. Atmos. Environ. 30: 639-648. 
Matsumoto, M. and Okita, T. (1998). Long Term Measurements of Atmospheric Gaseous Aerosol Species Using an Annular Denuder System in Nara, Japan. Atmos. Environ. 32: 1419-1425.

Padro, J., Hartog, G.D. and Neumann, H.H. (1991). An Investigation $\mathrm{OH}$ the ADOM Dry Deposition Module Using Summertime $\mathrm{O}_{3}$ Measurements Above a Deciduous Forest. Atmos. Environ. 25A: 1689-1704.

Pilinis, C., Seinfeld, J.H. and Seigneur, C. (1987). Mathematical Modeling of the Dynamics of Multicomponent Atmospheric Aerosols. Atmos. Environ. 21: 943-955.

Rastogi, N. and Sarin, M. (2006). Atmospheric Abundances of Nitrogen Species in Rain and Aerosols over a Semiarid Region: Sources and Deposition Fluxes. Aerosol Air Qual. Res. 6: 406-417.

Reddy, R.R., Rama, Gopal K., Narasimhulu, K., Siva Sankara Reddy, L. and Raghavendra Kumar, K. (2007). Aerosol Size Distribution Variation in Anantapur $\left(14.62^{\circ} \mathrm{N}, 77.65^{\circ} \mathrm{E}\right)$ Semi Arid Zone and Its Impact on Aerosol Effective Radius. Aerosol Air Qual. Res. 7: 550-562.

Seinfeld, J.H. (1986). Atmospheric Chemistry and Physics of Air Pollution, Wiley Interscience, New York.

Seinfeld, J.H. and Pandis, S.N. (1998). Atmospheric Chemistry and Physics from Air Pollution to Climate Change, John Wiley \& Sons, Inc., New York.

Tsai, C.J. and Perng, S.N. (1998). Artifacts of Ionic Species for Hi-vol $\mathrm{PM}_{10}$ and $\mathrm{PM}_{10}$ Dichotomous Sampler. Atmos. Environ. 32: 1605-1613.
Tsai, D.H., Wang, J.L., Wang, C.H. and Chan, C.C. (2008). A Study of Ground-level Ozone Pollution, Ozone Precursors and Subtropical Meteorological Conditions in Central Taiwan. J. Environ. Monit. 10: 109118.

Tsai, J.L. and Tsuang, B.J. (2005). Aerodynamic Roughness over an Urban Area and over Two Farmlands in a Populated Srea as Fetermined by Wind Profiles and Surface Energy Flux Measurements. Agric. For. Meteorol. 132: 154-170.

Tsuang B. J. (2003). Quantification on the Source/Receptor Relationship of Primary Pollutants and Secondary Aerosols by a Gaussian Plume Trajectory Model: Part ITheory. Atmos. Environ. 37: 3981-3991.

Tsuang, B.J., Chen, C.L., Lin, C.H., Cheng, M.T., Tsai, Y.I., Chio, C.P., Pan, R.C. and Kuo, P.H. (2003a). Quantification on the Source/Receptor Relationship of Primary Pollutants and Secondary Aerosols by a Gaussian Plume Trajectory Model: Part IICase Study. Atmos. Environ. 37: 3993-4006. Tsuang, B.J., Lee, C.T., Cheng, M.T., Lin, N.H., Lin, Y.C., Chen, C.L., Peng, C.M. and Kuo, P.H. (2003b). Quantification on the Source/Receptor Relationship of Primary Pollutants and Secondary Aerosols by a Gaussian Plume Trajectory Model: Part III-Asian Dust-storm Periods. Atmos. Environ. 37: 4007-4017.

Tsuang, B.J., Tsai, J.L., Lin, M.D., Chen, C.L. (2003). Determining Aerodynamic Roughness by Tethersonde and Heat Flux Measurements in an Urban Area over a 
Complex Terrain. Atmos. Environ. 37: 1993-2003.

US EPA. (1999). Determination of Reactive Acidic and Basic Gases and Strong Acidity of Atmospheric Fine Particles in Ambient Air Using the Annular Denuder Technology. Method IO-4, Center for Environmental Research and Development, Office of Research and Development, U.S. EPA, Cincinnati.

Vukovich, F.M., Bach, Jr.W.D., Crissman, B. W., and King, W.J. (1977). On the Relationship between High Ozone in the Rural Surface Layer and High Pressure Systems. Atmos. Environ. 11: 967-983.

Wang, C.C., Lee, C.T., Liu, S.C. and Chen, J.P. (2004). Aerosol Characterization at Taiwan's Northern Tip during Ace-asia. Terr Atmos Ocean Sci. 15: 839-855.

Wang, H.K., Chen, K.S., Lu, J.J., Peng, Y.P., Wang, W.C., Tsai, M.Y. and Lai, C.H. (2007a). Dry Deposition of Airborne Particles and Characteristics of Polycyclic Aromatic Hydrocarbons in Urban Kaohsiung, Taiwan. Aerosol Air Qual. Res. 7: 106-120.

Wang, J.H., Chang, C.C., Wang, J.L. (2005). Peak Tailoring Concept in GC Analysis of Volatile Organic Pollutants in the Atmosphere. J. Chromatography A. 1087: 150-157.

Wang, J.L., Wang, C.H., Lai, C.H., Chang, C.C., Liu, Y., Zhang, Y., Liu, S. and Shao,
M. (2008). Characterization of Ozone Precursors in the Pearl River Delta by Time Series Observation of Non-methane Hydrocarbons. Atmos. Environ. 42: 62336246.

Wang, W.C. and Chen, K.S. (2008a). Modeling and Analysis of Source Contribution of $\mathrm{PM}_{10}$ during Severe Pollution Events in Southern Taiwan. Aerosol Air Qual. Res. 8: 319-338.

Wang, W.C., Chen, K.S., Chen, S.J., Lin, C.C., Tsai, J.H., Lai, C.H. and Wang, S.K. (2008b). Characteristics and Receptor Modeling of Atmospheric $\mathrm{PM}_{2.5}$ at Urban and Rural Sites in Pingtung, Taiwan. Aerosol Air Qual. Res. 8: 12-129.

Wang, X.H., Ye, C.X., Yin, H.L., Zhuang, M.Z., Wu, S.P., Mu, J.L. and Hong, H.S. (2007b). Contamination of Polycyclic Sromatic Hydrocarbons Bound to $\mathrm{PM}_{10} / \mathrm{PM}_{2.5}$ in Xiamen, China. Aerosol Air Qual. Res. 7: 260-276.

Yang, K.L., Ting, C.C., Wang, J.L., Wingenter, O. W. and Chan, C.C. (2005). Diurnal and Seasonal Cycles of Ozone Precursors Observed from Continuous Measurements at an Urban Site in Taiwan. Atmos. Environ. 39: 3221-3230.

Received for review, December 21, 2008 Accepted, February 19, 2009 